Cadmium, like other heavy metals, is highly toxic, binding rapidly to extracellular and intracellular protein, and thus disrupting membrane and cell function. Immediate gastric washout and rapid chelation treatment are the most effective methods of treatment. In studies of animals chelation treatment has been shown to be effective only if given soon after ingestion of cadmium. ${ }^{4}$ Charcoal haemoperfusion is ineffective because of the high protein binding of cadmium.

Our patient had ingested a massive dose of $150 \mathrm{~g}$ of cadmium chloride, and, although the initial diagnosis was delayed, it seems unlikely that any treatment would have prevented the membrane dysfunction and destruction of tissue. The case, however, illustrates the catastrophic effects of ingested cadmium on organ function.

1 Lee JS, White KL. A review of the health effects of cadmium. Am f Ind Med 1980;1:307-17 2 Smith TL. Chronic cadmium exposure with kidney function effects. Am J Ind Med 1980;1:319-37. 3 Hallenbeck WH. Human health effects of exposure to cadmium. Experimenta i984;40:136-42.

4 Cantelina LR, Klassen CD. Decreased effectiveness of chelation therapy with time after acute cadmium poisoning. Toxicol Appl Pharmacal 1982;63:173-80.

(Accepted II March 1986)

Department of Medicine, Hope Hospital, University of Manchester School of Medicine, Salford $M 68 \mathrm{HD}$

H M BUCKLER, BMEDSCI, MRCP, tutor in medicine

W D F SMITH, MB, MRCP, medical registrar

W D W REES, MD, MRCP, consultant physician

Correspondence to: Dr Buckler.

\section{Assessment of thyroid function: complications after treatment with fenoprofen}

The assessment of thyroid function has become increasingly complex as more drugs have been shown to have either in vivo or in vitro effects. Amiodarone, for example, has been shown to induce antithyroid antibodies ${ }^{1}$ whereas fenclofenac interferes by displacing thyroxine from binding sites, resulting in an apparent decrease in the total thyroxine concentration. ${ }^{2} \mathrm{We}$ describe the previously unreported effects of fenoprofen on some biochemical variables used in the assessment of thyroid function.

\section{Patients, methods, and results}

During routine testing of thyroid function a 63 year old woman was found to have a raised free triiodothyronine concentration with normal thyroid stimulating hormone activity and slightly decreased free thyroxine concentration (free triiodothyronine concentration $=30 \mathrm{pmol} / 1(19.5 \mathrm{pg} / \mathrm{ml})$, normal range $=2.9$. $8.6 \mathrm{pmol} / 1(1.9 .5 .6 \mathrm{pg} / \mathrm{ml})$; thyroid stimulating hormone activity $=4.8 \mathrm{mU} / \mathrm{l}$, normal range $0.4-5.6 \mathrm{mU} / \mathrm{l}$; free thyroxine concentration $=8.8 \mathrm{pmol} / 1(6.9 \mathrm{pg} / \mathrm{ml})$, normal range $9 \cdot 4-25 \mathrm{pmol} / 1(7 \cdot 3-19 \cdot 5 \mathrm{pg} / \mathrm{ml}))$. As she was not clinically thyrotoxic drug interference was suspected. When treatment with fenoprofen was withdrawn her free triiodothyronine concentration fell to $5 \mathrm{pmol} / \mathrm{l}(3.3 \mathrm{pg} / \mathrm{ml})$, free thyroxine concentration rose to $11.8 \mathrm{pmol} / 1(9 \cdot 2 \mathrm{pg} / \mathrm{ml})$, and thyroid stimulating hormone activity remained within normal limits.

Range of thyroid stimulating hormone activity and free triodothyronine and free thyroxine concentrations in five healthy volunteers after taking fenoprofen

\begin{tabular}{|c|c|c|c|}
\hline $\begin{array}{l}\text { Tme after ingestion } \\
\text { of fenoprofen } \\
\text { (minutes) }\end{array}$ & $\begin{array}{l}\text { Thyroid stimulating } \\
\text { hormone } \\
(\mathrm{mU} / \mathrm{l})\end{array}$ & $\begin{array}{c}\text { Free } \\
\text { triiodothyronine } \\
(\mathrm{pmol} / \mathrm{l})\end{array}$ & $\begin{array}{c}\text { Free } \\
\text { thyroxinef } \\
(\mathrm{pmol} / \mathrm{l})\end{array}$ \\
\hline $\begin{array}{r}0 \\
90 \\
180 \\
300 \\
420\end{array}$ & $\begin{array}{l}1 \cdot 0-1 \cdot 2 \\
0 \cdot 8-1 \cdot 0 \\
0 \cdot 8-1 \cdot 0 \\
0 \cdot 8-1 \cdot 1 \\
0 \cdot 7-1 \cdot 2\end{array}$ & $\begin{array}{c}6 \cdot 8-8 \cdot 5 \\
15 \cdot 4-19 \cdot 8 \\
13 \cdot 2-14 \cdot 4 \\
10 \cdot 4-13 \cdot 0 \\
7 \cdot 6-11 \cdot 2\end{array}$ & $\begin{array}{l}14 \cdot 2-18 \cdot 0 \\
12 \cdot 8-16 \cdot 7 \\
12 \cdot 1-17 \cdot 3 \\
12 \cdot 0-17 \cdot 3 \\
11 \cdot 2-15 \cdot 4\end{array}$ \\
\hline Methodology & $\begin{array}{l}\text { Sensitive thyroid } \\
\text { stimulating hormone } \\
\text { assay (NETRIA) }\end{array}$ & $\begin{array}{c}\text { Amerlex M } \\
\text { (Amersham) }\end{array}$ & $\begin{array}{c}\text { Amerlex M } \\
\text { (Amersham) }\end{array}$ \\
\hline
\end{tabular}

*Normal range for men=0.4-3.7 mU/, for women $=0.4-4.9 \mathrm{mU} /$, and for postmenopausal women $=0 \cdot 4-5 \cdot 7 \mathrm{mU} /$.

tNormal range $=2 \cdot 9 \cdot 8 \cdot 6 \mathrm{pmol} / \mathrm{l}$.

$\neq$ Normal range $=9 \cdot 4-25 \mathrm{pmol} / 1$.

Conversion: SI to traditional wnits-Free triiodothyronine: $1 \mathrm{pmol} / \mathrm{l} \approx 1.5 \mathrm{pg} / \mathrm{ml}$. Free

thyroxine: $1 \mathrm{pmol} / \approx \approx 1 \cdot 3 \mathrm{pg} / \mathrm{ml}$.
To assess the effect that fenoprofen may have on the measured variables of thyroid function $300 \mathrm{mg}$ of fenoprofen (Dista Products) was taken by five healthy volunteers working in the laboratory, who were biochemically euthyroid and not receiving any other treatment. Blood samples were taken before they ingested fenoprofen and $90,180,300$, and 420 minutes afterwards. After the ingestion of fenoprofen all specimens showed a large increase in the free triiodothyronine concentrations, reaching a maximum, which was roughly twice the upper limit of normal, at 90 minutes and remaining raised for over seven hours (table). The thyroid stimulating hormone activity remained normal whereas the free thyroxine concentration decreased slightly by roughly $7 \%$ at 90 minutes and remained so for seven hours.

\section{Comment}

As the peak absorption of fenoprofen occurs between 60 and 120 minutes (Dista Products, personal communication) and the free thyroxine concentrations did not show a concomitant rise our results suggest a cross reaction or some interference with the free triiodothyronine assay.

Neither the manufacturer nor the Data Bank at Surrey University have of received any reports indicating the possible interference of fenoprofen with thyroid function or the assay of thyroid hormones. We therefore suggest that free triiodothyronine concentrations measured in patients taking fenoprofen should be interpreted with caution and that other analytical methods should be checked for comparable interference. We have extended these studies to other phenylpropionic derivatives of the arylalkanoic acids and have found that flurbiprofen interferes in the same way as fenoprofen but ibuprofen (as Nurofen) does not interfere.

1 Monteiro E, Galväo-Teles A, Santos ML, et al. Antithyroid antibodies as an early marker for thyroid disease induced by amiodarone. Br Med f 1986;292:227-8.

2 John R, Kadbury S, Woodhead JS, Pritchard MH. Fenoclofenac and thyroid function tests. Ann Clin Biachem 1983;20:381-2.

(Accepted II Marck 1986)

Department of Clinical Chemistry, Southend Hospital, Westcliff on Sea, Essex SSO ORY

J R GURNEY, BSC, PHD, senior biochemist

R J MILLS, PHD, FRSC, top grade biochemist

Correspondence to: Dr Gurney.

\section{Lyme disease in a Hampshire child- medical curiosity or beginning of an epidemic?}

In 1975 in the town of Old Lyme, Connecticut, a group of children was investigated for recurrent attacks of arthritis, mainly affecting larger joints. ${ }^{1}$ Over a quarter of the affected children had had an antecedent tick bite that developed into an expanding erythematous lesion typical of erythema chronica migrans. Follow up studies of "Lyme disease" showed it to be a complex multisystem disorder, the manifestations of which include erythema chronica migrans; flitting arthralgia; arthritis (mainly affecting large joints and possibly erosive); varying degrees of atrioventricular block, myocarditis, pericarditis; meningitis, encephalitis, cranial neuropathy (commonly VII nerve palsy), peripheral radiculoneuropathy; and lethargy, fatigue, non-productive cough, and muscular aches.

The causal agent has been identified as the spirochaete Borrelia burgdorferi, which is sensitive to penicillin and tetracycline. The vector is the ixodid species of tick, and the reservoir is usually a deer. Since Lyme disease was first recognised the number of reported cases has reached epidemic proportions in many American states and isolated reports have emerged from Europe and Australia. ${ }^{24}$ In the United Kingdom a 15 year old boy was reported to have erythema chronica migrans but no other manifestations of Lyme disease. ${ }^{5}$ We report on a 9 year old boy with classic features and serological evidence of Lyme disease, probably acquired in Hampshire.

\section{Case report}

A previously healthy 9 year old boy was admitted to hospital in August 1985 with an eight day history of fatigue, headache, neck stiffness, and photophobia. Three weeks earlier he had been bitten by a tick on his back during a visit to a local country park. At the site of the bite he developed an expanding erythematous lesion, which spread to $30 \mathrm{~cm}$ in diameter. This rash subsided over the next five days. He had no other symptoms. 
On examination he had no fever but had notable photophobia and nuchal rigidity. There were no other abnormal physical findings. Investigations showed that he had a normal full blood count and an erythrocyte sedimentation rate of $3 \mathrm{~mm}$ in one hour. His cerebrospinal fluid was under normal pressure with a leucocyte count of $1045 \times 10^{6} / \mathrm{l}$ (all mononuclear cells). Cultures, including that for mycobacterium tuberculosis, were negative. Serological testing for cytomegalovirus, herpes simplex, adenovirus, varicella zoster, mumps, Epstein Barr virus, and arbovirus antigen (including tick borne encephalitis virus) gave negative results. Clinically the boy slowly improved without specific treatment but he had continuing lethargy, fatigue, and sporadic arthralgia but no overt arthritis.

A month after his original presentation he was found disorientated and dysphasic, with nuchal rigidity, but no fever. He also had papilloedema, right sided hemiparesis, and a right facial palsy. A computed tomogram was normal and an electroencephalogram was consistent with meningoencephalitis. His cerebrospinal fluid was again examined. The white cell count was $374 \times 10^{6 / 1}$, protein was raised at $2100 \mathrm{mg} / \mathrm{l}$, and results of bacteriology were negative. Over 48 hours his neurological signs resolved. Serological investigations confirmed antibodies to $B$ burgdorferi at a titre of $1 / 1024$, confirming recent infection by this organism. Subsequently he steadily improved, although he still complained intermittently of fatigue, lethargy, headache, arthralgia, and a non-productive cough.

\section{Comment}

When questioned veterinary and forestry professionals in the New Forest and adjacent areas reported no recent imports of deer or changes in the density of tick infestation. We know that many children and adults are bitten by ticks locally but we have never been given or spontaneously sought a history of tick bite or erythema chronica migrans. We cannot say whether our patient is an isolated curiosity, whether this particular illness has always been with us but unrecognised, or whether we may find ourselves with a new disease on our doorstep. We await the summer with interest.

1 Steere A, Malawista S, Bartenhagen N, et al. The clinical spectrum and treatment of Lyme disease. Yale f Biol Med 1984;57:453-6

2 Sturfelt G, Cavell B. Lyme disease in a 12 year old girl. Acta Paediatr Scand 1985; 74:133-6.

3 Stewart A, Glass J, Patel A, Watt G, Cripps A, Clancy R. Lyme arthritis in the Hunter Valley. Mcd J Aust 1982;1:139.

4 Gerster JC, Guggi J, Perroud H, Bovel R. Lyme disease appearing outside the United States. A case report from Switzerland. Br Med J 1981:283:951-2.

5 Obasi O. Erythema chronica migrans. Br f Dermatol 1977;97:459.

(Accepted 8 April 1986)

Paediatric Medical Unit, Southampton General Hospital, Southampton SO9 4XY

D WILLIAMS, MB, MRCP, paediatric registrar

C J ROLLES, MB, FRCP, consultant paediatrician

Department of Dermatology, Royal South Hants Hospital, Southampton

J E WHITE, MD, FRCP, consultant dermatologist

Correspondence to: Dr Rolles.

\section{Asthma caused by pulverised fuel ash}

Pulverised fuel ash is the residue that remains when pulverised coal is burnt in power stations. Low grade coal, ground to a particle size of $0 \cdot 1-100 \mu \mathrm{m}$, is blown into boilers in jets of airborne coal particles, and the residual ash is collected in electrostatic precipitators. Pulverised fuel ash is an important byproduct of the power industry: it is used for land filling and, because it sets hard in the presence of lime and water, is widely used as a building material in breeze blocks. It has not previously been reported as causing asthma. We report a case of asthma in a worker at a power station that was caused by inhalation of pulverised fuel ash.

\section{Case report}

Nine months after starting work as a plant attendant at a power station a 27 year old man developed episodes of shortness of breath with wheezing, which improved at weekends and during holidays. His work included cleaning the filters of the bags. On two occasions he was admitted to hospital with acute severe asthma. He had suffered from hay fever since childhood, and skin prick tests with extracts of grass pollen and house dust elicited immediate reactions.

He recorded his peak expiratory flow rate every two hours for 28 days. ${ }^{1}$ This deteriorated during work and improved when he was away from work. He underwent single blind occupational type inhalation tests. ${ }^{2}$ Tipping of $250 \mathrm{~g}$ of lactose and $2.5 \mathrm{~g}$ of charcoal (producing a dust that looked like pulverised fuel ash) for 30 minutes elicited no change in his forced expiratory volume in one second, but tipping of $250 \mathrm{~g}$ of lactose with $2.5 \mathrm{~g}$ of pulverised fuel ash provoked a late asthmatic reaction (figure). This late reaction was reproduced by a second inhalation test with the ash. The concentration of histamine required to cause a $20 \%$ fall in forced expiratory volume decreased from $12 \mathrm{mg} / \mathrm{ml}$ one day before the inhalation test with pulverised fuel ash to $2.5 \mathrm{mg} / \mathrm{ml} 24$ hours after the test. Serum neutrophil chemotactic activity increased by $120 \%$ during the late asthmatic reaction. ${ }^{3}$

After these results he was relocated at work to prevent him being exposed to pulverised fuel ash any longer. He remained free of symptoms and required no treatment. Serial measurements of peak expiratory flow rate after he was relocated showed no evidence of asthma.

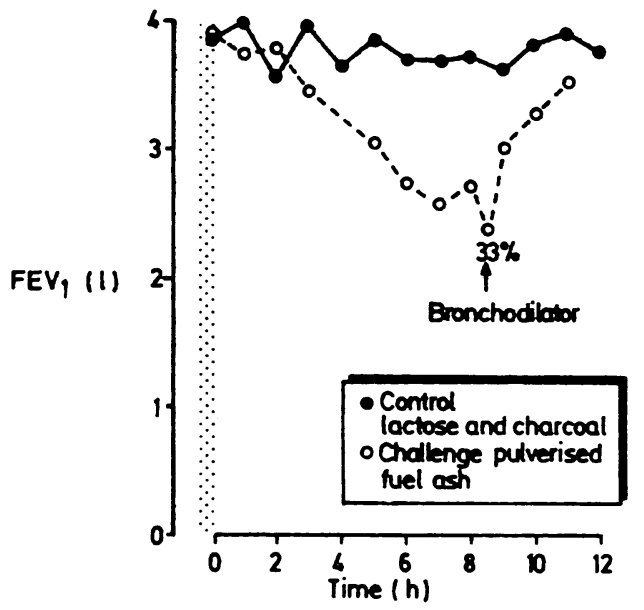

Inhalation test with challenge period shaded.

\section{Comment}

This patient's symptoms suggested that he had developed asthma related to his work, and this was confirmed by the results of serial measurements of his peak expiratory flow rate. Inhalation testing with pulverised fuel ash, to which he was exposed at work, provoked a reproducible asthmatic reaction. This late response was associated with a rise in serum neutrophil chemotactic activity (measured during the second inhalation test). The interval of nine months before the onset of his symptoms, the late asthmatic reaction provoked by the inhalation test with pulverised fuel ash, the associated increase in airway reactivity, ${ }^{4}$ and the resolution of asthma after relocation at work suggest that pulverised fuel ash was the primary cause of this man's asthma.

Pulverised fuel ash is a complex material: $60-80 \%$ of its weight is made up of water insoluble aluminosilicates, $15-30 \%$ of crystals (the main species being mullite, magnetite, carbon, and quartz), and the remaining $2-4 \%$ of water soluble sulphates of calcium, sodium, and potassium with trace quantities of arsenic, boron, copper, molybdenum, and selenium. ${ }^{5}$ We did not identify which of these materials, either alone or in combination, caused our patient's asthma.

Some 12 million tons of pulverised fuel ash are produced each year in the United Kingdom and 50 million tonnes each year in the United States. The greatest risk of developing asthma due to inhaled pulverised fuel ash is run by those working in the power and construction industries.

1 Burge PS, O'Brien IM, Harries MG. Peak flow in the diagnosis of occupational asthma due to colophony. Thorax 1979;34:308-16.

2 Newman Taylor AJ, Davies R. Inhalation challenge testing in occupational lung diseases: research approaches and methods. New York: Marcel Dekker, 1981.

3 Nagy L, Lee TH, Kay AB. Neutrophil chemotactic activity in antigen induced late asthmatic reactions. $N$ Engl 7 Med 1982;306:497-501.

4 Cartier A, Thomson NC, Frith PA, et al. Allergen induced increase in bronchial responsiveness to histamine: relationship to the late asthma response and change in airway calibre. $f$ Allergy Clin Imomunol 1982;70:170-7.

5 Raask E, Schilling CJ. Research findings on the toxicity of quartz particles relevant to pulverised fuel ash. Ann Occup Hyg 1980;23:147-57.

(Accepled 24 February 1986)

Brompton Hospital and Cardiothoracic Institute, London SW3

ANTHONY G DAVISON, BSC, MRCP, senior registrar

S DURHAM, MA, MRCP, lecturer

A J NEWMAN TAYLOR, MSC, MRCP, consultant physician, director, department of occupational medicine

Central Electricity Generating Board, South Eastern Region, Bankside House, London SE1

C J SCHILLING, MSC, MRCP, regional medical officer

Correspondence to: Dr Davison. 